\title{
Invasive versus native brachyuran crabs in a European rocky intertidal: respiratory performance and energy expenditures
}

\author{
Simon Jungblut ${ }^{1,2} \cdot$ Karin Boos ${ }^{1,3} \cdot$ Morgan L. McCarthy $^{1,2,4} \cdot$ Reinhard Saborowski $^{2} \cdot$ Wilhelm Hagen $^{1}$
}

Received: 14 July 2017 / Accepted: 10 February 2018

(c) Springer-Verlag GmbH Germany, part of Springer Nature 2018

\begin{abstract}
The invasive Asian shore crab Hemigrapsus sanguineus is now the second most abundant intertidal crab in the North Sea after the native European green crab Carcinus maenas. To compare their respiratory performance and energy expenditures, we measured standard respiration rates of both species from around the island of Helgoland, North Sea, Germany $\left(54^{\circ} 11^{\prime} \mathrm{N}\right.$, $7^{\circ} 53^{\prime} \mathrm{E}$ ) in 2015 . Oxygen consumption was recorded in a flow-through setup between 5 and $20^{\circ} \mathrm{C}$. At lower temperatures, $H$. sanguineus had similar respiration rates as C. maenas, but approximately twofold higher rates at higher temperatures. Numerical models for the calculation of individual respiration rates were established and applied to the entire intertidal populations around Helgoland to compare the energy expenditures of both species. Abundance and biomass data recorded in August 2014 showed that $H$. sanguineus reached values as high as 21 and 59\%, respectively, compared to those of C. maenas. Based on these data and the numerical respiration models, the energy expenditures of both populations were calculated for the whole year 2014. The H. sanguineus population reached, depending on the assumed diet of both species (complete herbivory versus complete carnivory), $86-135 \%$ of the expenditure value of C. maenas. As population densities of $H$. sanguineus are likely to increase in the North Sea, the energy expenditure of the invader and thus its impact on the energy flux in the intertidal habitat will further increase. Whether this will lead to an impact on the local intertidal community depends on species-specific dietary preferences and remains to be investigated.
\end{abstract}

Responsible Editor: H.-O. Pörtner.

Reviewed by M. Berggren and undisclosed experts.

Electronic supplementary material The online version of this article (https://doi.org/10.1007/s00227-018-3313-3) contains supplementary material, which is available to authorized users.

Simon Jungblut

jungblut@uni-bremen.de

Karin Boos

kboos@marum.de

Morgan L. McCarthy

morgan.mccarthy@jhu.edu

Reinhard Saborowski

reinhard.saborowski@awi.de

Wilhelm Hagen

whagen@uni-bremen.de

\section{Introduction}

Biological invaders are generally seen as a major threat to biodiversity in the marine realm (Grosholz 2002). Potentially, they may drastically change the native community structure and the function of an ecosystem. If the ecological impact is high, ultimately, ecosystem services and thus human economic interest and health may be affected (Ruiz et al. 2000; Simberloff et al. 2013).

Species of brachyuran decapods frequently invade coastal and marine ecosystems (Brockerhoff and McLay 2011). Due

1 Bremen Marine Ecology (BreMarE), Marine Zoology, University of Bremen, P.O. Box 330440, 28334 Bremen, Germany

2 Alfred Wegener Institute, Helmholtz Centre for Polar and Marine Research, P.O. Box 120161, 27570 Bremerhaven, Germany

3 MARUM, Center for Marine Environmental Sciences, University of Bremen, Leobener Straße 8, 28359 Bremen, Germany

4 Department of Earth and Planetary Sciences, Johns Hopkins University, 3400 N Charles Street, Baltimore, MD, USA 
to their pronounced invasion potential, two of these species are relatively well studied: the European green crab Carcinus maenas and the Asian shore crab Hemigrapsus sanguineus. The first is native to European and African coasts of the North Atlantic. It invaded the coasts of North America by 1817 (Carlton and Cohen 2003). Subsequently, C. maenas appeared on coasts all around the world, including the North American Pacific coast, South Africa, Australia, and Japan (Carlton and Cohen 2003). The latter, H. sanguineus, is native to Japanese, Korean, and Chinese coasts. It invaded the Atlantic coasts of North America in the late 1980's and the European Atlantic coasts in the late 1990's (Stephenson et al. 2009). On the Atlantic coasts of North America, $H$. sanguineus can be found from Cape Hatteras in North Carolina up to the Schoodic Peninsula in Maine (Williams and McDermott 1990; Delaney et al. 2008; Epifanio 2013). Its current European distribution ranges from the French Atlantic coast to the German Wadden Sea (Dauvin et al. 2009). A few specimens were also reported in the Adriatic Sea, the Black Sea and the Swedish Skagerrak (Schubart 2003; Micu et al. 2010; M. Berggren, Sven Lovén Centre for Marine Sciences-Kristineberg, Fiskebäckskil, Sweden, pers. comm.).

The ecology and physiology of $C$. maenas is well studied (e.g., Crothers 1967; Roman and Palumbi 2004; Breen and Metaxas 2012 and references therein). Ecological information on $H$. sanguineus is growing, mostly from invaded areas, where increasing numbers of $H$. sanguineus share habitats and possibly compete for resources with $C$. maenas (for native areas, e.g., Fukui 1988; Lohrer et al. 2000a; for invaded areas, e.g., McDermott 1998; Jensen et al. 2002; Lohrer and Whitlatch 2002; Epifanio 2013 and references therein; Jungblut et al. 2017). However, physiological data of $H$. sanguineus are rather scarce (Breen and Metaxas 2012) and stem mostly from the invaded US east coast. For instance, the species was identified as an income breeder, meaning that it utilizes energy ingested during reproductive times directly for egg production (Griffen et al. 2012). Furthermore, respiration rates of $H$. sanguineus were not affected by algal diet, however, rates increased with the amount of consumed animal diet due to the increasing costs for digestion (Griffen et al. 2015). In the same study, two condition parameters, hepatosomatic index and hepatopancreas total lipid content, increased with increasing consumption of animal diet, but not with increasing amounts of algal diet.

Respiration, integrating all aerobic metabolic processes of an organism, can serve as a proxy of the energetic impact that an organism has on its environment via food uptake (Brey 2010). These physiological processes include transformation of energy and matter. They require the uptake of $\mathrm{O}_{2}$ (respiration) and release $\mathrm{CO}_{2}$ (Ikeda et al. 2000). Hence, respiration rates can be used to calculate carbon uptake, metabolic energy expenditures and, thus, the energetic impact of an organism on its habitat in terms of food uptake (Ikeda et al. 2000). Body mass of an organism and ambient temperature are the most important predictors for estimating aquatic invertebrate respiration rates (Brey 2010). Models for the calculation of respiration from mass and temperature are available for marine pelagic copepods (Ikeda et al. 2007), for calanoid copepods (Bode et al. 2013), euphausiids (Ikeda 2013), and some decapod species (e.g., Crear and Forteath 2001).

Based on the success of $H$. sanguineus in newly invaded areas, we hypothesized that this species has physiological advantages over the native species $C$. maenas. Furthermore, $H$. sanguineus may take up oxygen at higher rates, and therefore, may also have higher energy expenditures compared to $C$. maenas. Thus, (1) standard respiration rates of both species with regard to biomass, temperature, season, and sex were measured between 5 and $20^{\circ} \mathrm{C}$, the temperature range both species naturally experience in their habitat. Based on these data we (2) established temperature- and mass-dependent respiration models for both species. These models were applied to (3) calculate the energy expenditures of both entire intertidal populations around Helgoland to compare the energetic impact of both crab species on their habitat.

\section{Materials and methods}

\section{Origin of animals}

Carcinus maenas and Hemigrapsus sanguineus were collected in April, June, and August 2015 during low tide at an intertidal site at the southwestern tip ('Kringel') on the island of Helgoland, southern North Sea, Germany $\left(54^{\circ} 10^{\prime} 36.5^{\prime \prime} \mathrm{N}, 7^{\circ} 53^{\prime} 03.3^{\prime \prime} \mathrm{E}\right)$. The collection site is waveexposed and the intertidal is composed of many small and large rocks, boulders, as well as coarse sand patches. Hard structures were covered by small to medium-sized macroalgae. Dominating species were Ulva spp., Enteromorpha spp., Fucus serratus, Chondrus crispus, and Mastocarpus stellatus. For habitat details refer to Bartsch and Tittley (2004). Monthly mean seawater temperatures were $7.6 \pm 0.8$ in April, $13.4 \pm 0.8$ in June and $17.7 \pm 0.4{ }^{\circ} \mathrm{C}$ in August (mean $\pm \mathrm{SD}$, seawater temperature data of the Helgoland Ferrybox, downloaded from the COSYNA data web portal http://codm.hzg.de/codm/).

Oxygen consumption measurements were conducted with crabs of carapace widths from 10 to $40 \mathrm{~mm}$, as those were most abundant in the intertidal areas (Jungblut et al. 2017). Also, no $H$. sanguineus specimen was found with a carapace width above $40 \mathrm{~mm}$. To keep both datasets comparable by individual mass, no $C$. maenas above $40 \mathrm{~mm}$ were used. 
Throughout their molt cycle, C. maenas change their carapace color from greenish to reddish and alter behavior and physiology (reviewed by Styrishave et al. 2004). Red color morphs of $C$. maenas showed a higher oxygen uptake rate than green ones (Reid and Aldrich 1989). As red color morphs of $C$. maenas are very rare in the Helgoland intertidal, they were not considered in this study. Moreover, molting and ovigerous decapod crabs showed higher respiration rates (e.g., Lewis and Haefner 1976; Naylor et al. 1997). Therefore, we only included crabs in the inter-molt phase with hard carapaces and we excluded ovigerous females. Very few individuals, which molted during the respiration measurements, were also excluded from the analysis.

\section{Respirometer}

Oxygen consumption of the crabs was measured with a custom-built flow-through respirometer (Fig. 1a) installed on a movable laboratory trolley. Temperature-controlled aerated seawater flowed from a 100-L tank through the supply hose passing an oxygen-sensitive and fluorescent foil glued to the inner side of an acrylic holder (Fig. 1b, inflow measuring point). Thereafter, the tube branched out to supply eight cylindrical acrylic glass respiration chambers of approx. $475 \mathrm{~mL}$ or, in case of crabs with a carapace width $<15 \mathrm{~mm}$, approx. $190 \mathrm{~mL}$ volume (Fig. 1c). Behind each chamber, the water passed another oxygen-sensitive foil (outflow measuring point), a hose pump, and was directed to the sink. Each acrylic holder had a fiber-optic cable placed directly opposite of the oxygen-sensitive foil. The cable transmitted a light impulse from a 10-channel Fiber-Optic Oxygen Meter
(OXY-10, PreSens, Precision Sensing GmbH, Regensburg, Germany) to the foil and the emitting light back to the device. A laptop computer recorded the phase angle shifts between impulse and signal, which depended on the seawater oxygen concentration in the nine measurement channels used (one entrance and eight exit measuring points). The recording software transformed the phase angle shifts to oxygen concentrations.

The oxygen meter was calibrated with fully aerated and oxygen-free seawater at a given temperature and salinity. Prior to starting a new series of measurements, the new temperature value was entered into the recording software to adjust the oxygen concentration values. Salinity was the same during calibration and measurements and did not need to be adjusted.

\section{Respiration measurements}

After sampling, the crabs were immediately transferred to the laboratories of the Marine Station and kept for $24 \mathrm{~h}$ in plastic aquaria in the dark at $10{ }^{\circ} \mathrm{C}$ and a salinity of approx. 32.5 to standardize hunger levels and to let the crabs clear their gut. The carapace width of each crab was measured with Vernier calipers to the nearest $0.5 \mathrm{~mm}$. The animals were carefully blotted dry with paper towels for $10 \mathrm{~s}$ and weighed to the nearest $0.001 \mathrm{~g}$ to obtain their fresh mass.

Each set of measurements (seven crabs and a random control) was performed at consecutively increasing temperatures of $5,10,15$, and $20{ }^{\circ} \mathrm{C}$. The laboratory trolley with the respirometer was gently rolled into the respective temperature-controlled room, aeration in the supply tank was
Fig. 1 Custom-designed respirometer, a water flow during respiration measurements. Tubes between the two measuring points were gas-tight, $\mathbf{b}$ acrylic holder for oxygensensitive foil and $\mathbf{c}$ respiration chamber with Carcinus maenas inside. (photos: S. Jungblut)
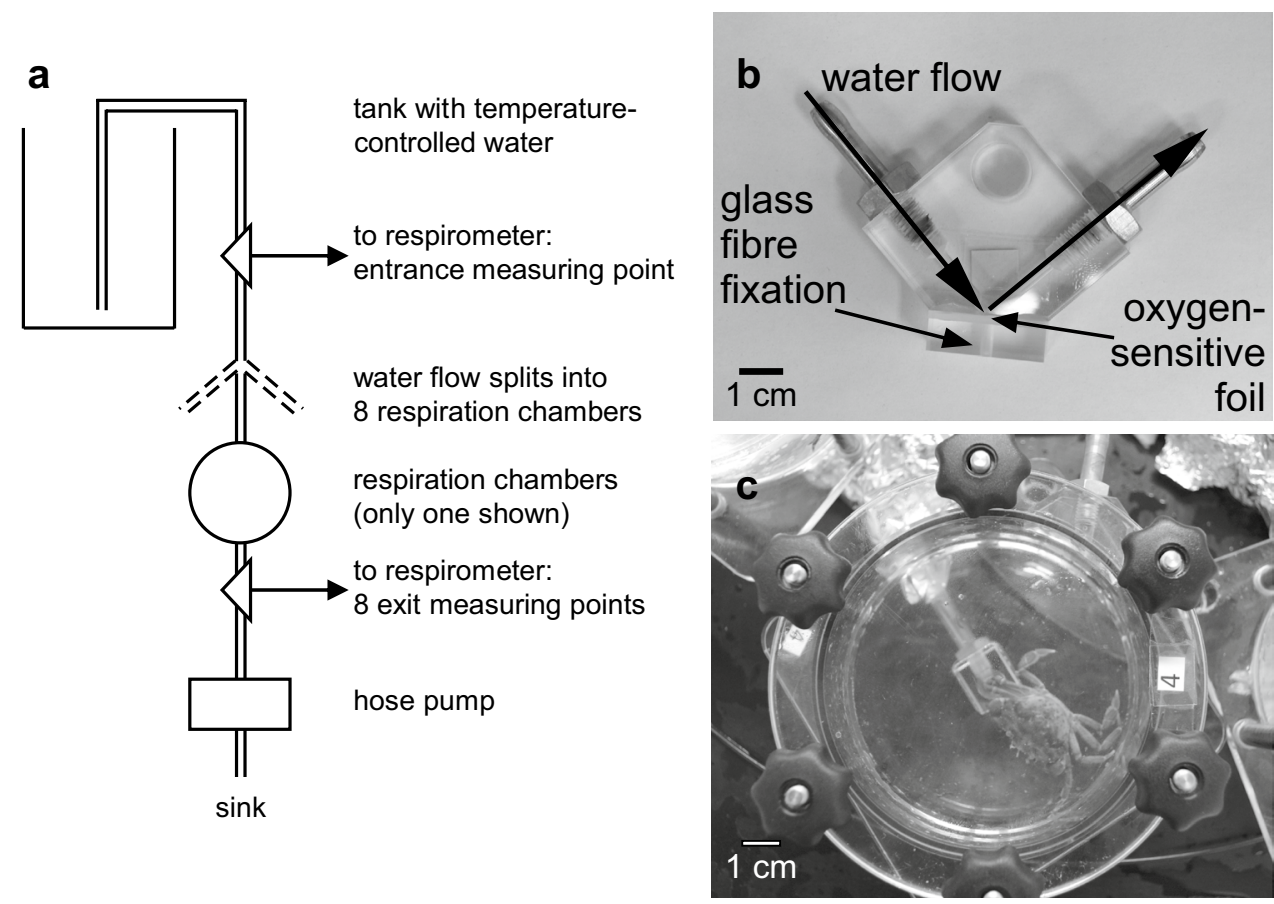
switched off, and the supply hose of the respirometer was connected to the tank. The seawater used for the measurements had a salinity of approx. 32.5 and never deviated more than $\pm 0.5^{\circ} \mathrm{C}$ from the target temperature. Oxygen concentration measurements were performed once a minute for $8 \mathrm{~h}$ per temperature.

Initial gut clearance and the actual measurements took place in the dark to avoid visual stimuli of the crabs, i.e., seeing other crabs through the transparent respiration chambers. Furthermore, oxygen consumption was lower and thus closer to the resting metabolic rates in darkness compared to measurements under the natural light/dark conditions in other intertidal Hemigrapsus species (Dehnel 1958).

In preliminary experiments, the required flow rates for different sizes of crabs were determined to avoid oxygen concentrations below 70\%. These experiments showed that within $3 \mathrm{~h}$, oxygen concentration readings reached a plateau. This indicates that the water temperature in the respiration chambers had adjusted and the crabs had acclimated to the new temperature. Thus, these first $3 \mathrm{~h}$ of each measurement were omitted to account for handling stress and temperature acclimation of the crabs. The remaining $5 \mathrm{~h}$ of data collection provided about 300 measurements per crab and temperature.

In total, 63 C. maenas (31 males, 32 females) and $64 H$. sanguineus ( 32 males, 32 females) were measured at the four different temperatures.

\section{Data processing}

Differences between the seawater oxygen concentrations at the joint inflow and at the outflow of each respiration chamber were calculated. These oxygen consumption rates were corrected for unspecific signal fluctuation from the control chamber and values were standardized to the fresh mass of the respective crab.

Data were processed and figures were produced with the GraphPad Prism software (version 5.03). For each set of about 300 measurements per crab and temperature, a frequency distribution with bin width 1 and lower limit 0 was established. Natural logarithms of the minimum, median, and maximum values of these frequency distributions were used to obtain linear regressions between mass-specific respiration and crab mass for each incubation temperature. These linear regressions were used to calculate individual respiration rates of standardized crabs of $0.5,5$, and $10 \mathrm{~g}$ fresh mass at each temperature. The minimum values, i.e., the smallest measured value per crab, represent the standard or resting respiration rates. For these, the $Q_{10}$ temperature coefficients were calculated with van't Hoff's generalization:

$Q_{10}=\left(R_{2} / R_{1}\right)^{10\left(T_{2}-T_{1}\right)}$,
$R_{1}$ and $R_{2}$ are the metabolic rates, in this case respiration rates, and $T_{1}$ and $T_{2}$ the corresponding temperatures (Ikeda et al. 2000; Willmer et al. 2000).

\section{Statistical analysis and respiration models}

The standard respiration rates, calculated as daily oxygen uptake, were modelled as a function of the following main effects: species (C. maenas and $H$. sanguineus), month (April, June, and August), sex (male and female), temperature $\left(5,10,15\right.$, and $20^{\circ} \mathrm{C}$ as a covariate) and individual fresh mass (as covariate). During the modelling the factors sex and month were found to be insignificant for the different crab groups (see section "Results") and these factors were omitted from the model. Empirical regression models were described in detail for zooplankton organisms. In these models, $R$ represents the respiration rate, $m$ the individual's biomass and $T$ the temperature. Derived from the empirical relationships between respiration and biomass, $R=a \cdot m^{b}$ and $R=c \cdot d^{T}$ (with $a, b, c, d$ as constants), the regression model is as follows:

$\ln R=a^{0}+a^{1} \times \ln m+a^{2} \times T$,

(e.g., Ikeda 1985; Ikeda et al. 2007; Bode et al. 2013; Ikeda 2013). In the main model, all factors were included. For the establishment of the respiration models, however, we constructed two species-specific models, which only included the factors mass and temperature. All statistical models were fitted in R, version 3.2.3 (R Development Core Team 2015) using the functions 'Imer' from the package 'Ime4' (Bates et al. 2015) and 'lm' from the generic stats package for the reference models. In all models, we checked the following diagnostics for model stability: Cook's distance and mdffits from the package 'HMLdiag' for lmerMod class objects in R (Loy and Hofmann 2014). In all models, the checks confirmed the absence of influential cases.

\section{Main model}

The main model included three interactions of first order: we combined species with either sex, temperature or ln body mass, to test, whether these three factors were affecting respiration differently in the two species.

Each individual was measured consecutively at each of the four temperatures. Since these measurements represent longitudinal data, and consecutive data points are dependent data, we treated temperature as a within-subject's factor and included temporal nesting into the model by including a random factor, where individual is nested in time. Although the factor month was non-significant, the individuals used in the present experiment were still collected in three seasonally distinct batches. Hence, it seems reasonable to include 'month' as a random factor 
to control for any grouping effects over season. Because the temporal nesting was individual-specific, the seasonal grouping effect was already accounted for by the random nested term. For the model defined above, the choice of a general linear mixed effects model (LMM) was most appropriate.

We fitted the model using the maximum-likelihood method. With the ln-transformed response variable (see above) we met the assumptions of normal distribution. The variances of the residuals were slightly skewed but within acceptable ranges to meet the assumptions and accept the model. To establish the significance of individual terms, we conducted likelihood ratio tests (LRT) using the R-function 'anova' with the argument 'test' set to ' $F$ '. Hereby, we compared the deviances of the respective full model with the corresponding reduced model not comprising the respective factor and/or term of interest. When testing for main factors, which were combined into a random factor, we created reference models, from which we omitted the respective random factors and subsequently applied the LRT for our term of interest (e.g., species and temperature). Non-significant interactions and terms were removed from the previous full model (main factors sex and month, see 'Results').

\section{Respiration models}

The data were also used to establish mass- and temperature-specific respiration models for C. maenas and $H$. sanguineus. Therefore, we separated the final model into two species-specific models. Both included only the main factors temperature and $1 n$ of mass (which were shown to be the significant main factors), as well as the random within-subjects-factor (individual nested in temperature). The coefficients of each model were then used to establish a respiration model for rates of the two individual species from habitats, where information on temperature and biomass was available. Thereby, however, we used only the coefficients of the fixed effects (i.e., intercept and slopes for temperature and mass), which could then be multiplied with empirical measurements of temperature and $\ln$ of mass. For the final predictions in the actual scale, the inverse natural exponential function was applied to the ln-transformed predictions. We omitted the random term (subject nested in temperature) in the equation for the calculations of respiration rates, because they are only relevant for the present experimental design. In fact, future data might be collected in other months than those given in the present model. In addition, the estimates should not be specific for individual animals that were used in the present experiment, but should reflect individuals of a certain species in general.

\section{Energy expenditures of the Helgoland crab populations}

We assessed the energetic impact of the $C$. maenas and $H$. sanguineus populations onto their rocky intertidal habitat around the island of Helgoland via their food uptake, similar to a procedure used by $\mathrm{Hu}$ et al. (2012). Population respiration and energy expenditures were calculated based on the respiration models developed in this study, as well as the abundance and biomass data of both species from the four main intertidal sites in August 2014 (Table 1). For the calculation of a crab's energy expenditure, each individual was assigned its theoretical species-specific standard respiration via the respective respiration model. The average seawater temperature in August 2014 was $18.4 \pm 0.8^{\circ} \mathrm{C}$ (mean \pm SD, seawater temperature data of the Helgoland Ferrybox downloaded from the COSYNA data web portal http://codm.hzg. de/codm/). Considering its mass, the total daily respiration of each crab was calculated. By multiplication with the respiratory coefficient, the daily respiration was transformed into the daily $\mathrm{CO}_{2}$ release (Gnaiger 1983). Respiratory coefficients depend on the ingested food and range from 1 (herbivory) to 0.8 (carnivory) (Willmer et al. 2000). Since the feeding preferences of both species are not yet clear around Helgoland, we calculated the daily energy expenditure for both extremes. The daily $\mathrm{CO}_{2}$ release was multiplied by the molar mass of carbon $\left(12 \mathrm{~g} \mathrm{~mol}^{-1}\right)$ to obtain the daily carbon uptake. As $1 \mathrm{~g}$ organic carbon equals $41.4 \mathrm{~kJ}$ stored energy (Salonen et al. 1976), the daily metabolic energy expenditure $E\left(\mathrm{~kJ} \mathrm{~d}^{-1}\right)$ for each crab can be calculated:

$E=R \times m \times \mathrm{RQ} \times 12 \times 10^{-6} \times 41.4$,

with $R\left(\mu \mathrm{mol} \mathrm{g} \mathrm{g}^{-1} \mathrm{~d}^{-1}\right)$ as the previously calculated respiration rate of the crab, the crab's body mass $m(\mathrm{~g})$ and the respiratory quotient $R Q$ (ratio, no unit). By summing up all of the individual energy expenditure values per species, the daily energy expenditure was calculated per square meter and day for each of the four main intertidal sites around Helgoland. Multiplying these values with the spatial area of each site, the total energy expenditures of each species for each site were calculated. Therefore, the spatial areas (excluding large tide pools and concrete blocks) of the four main sites were established on the basis of the GIS map published by Bartsch and Tittley (2004) (H. Pehlke, Alfred Wegener Institute for Polar and Marine Research, Bremerhaven, Germany, pers. comm.). Summing up the four energy expenditure values resulted in two species-specific values for the whole Helgoland intertidal area.

In the same way as described above, we calculated the metabolic energy expenditure for the other months and the cumulative value of the year 2014 for both species. The calculations used monthly means of seawater temperature for the respiration models (seawater temperature data of the 


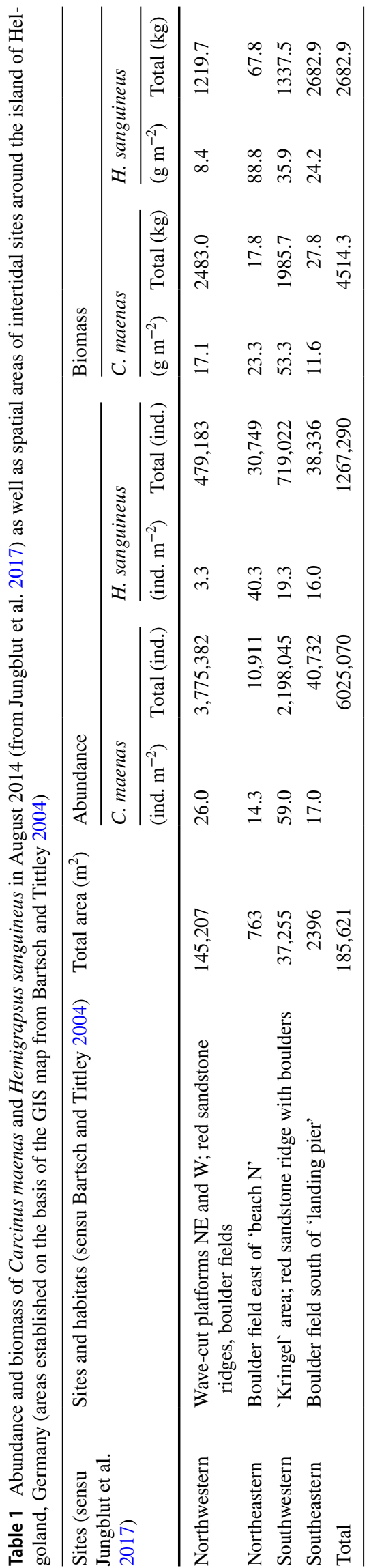

lightship "German Bight" downloaded from the COSYNA data web portal http://codm.hzg.de/codm/). In contrast to the abundance and biomass data of both crab species from August 2014 (Table 1), only semi-quantitative data of $C$. maenas abundance were available for the Helgoland intertidal from the mid-1980s (Janke 1986). As the latter data are relatively old and $H$. sanguineus was not present in the Helgoland area at that time, the calculations were based on the data from August 2014. However, Janke (1986) described an absence of $C$. maenas from the Helgoland intertidal areas from November to February, due to migration to subtidal areas. This phenomenon was also described for Danish waters (Aagaard et al. 1995) and was again recently observed for Helgoland (S. Jungblut, pers. obs.). Therefore, C. maenas was excluded from the calculations for the 4 months of absence, as this species does not contribute to the energy flux in the intertidal during this period. In contrast, $\mathrm{H}$. sanguineus is present in the intertidal year-round (S. Jungblut, pers. obs.) and was included in the calculations also during winter.

\section{Results}

\section{Oxygen consumption}

Respiration rates were measured in April, June, and August 2015. No seasonality effect was apparent, when both species were tested together $\left(\mathrm{LRT}_{\text {Month }}: d f=2, \chi^{2}=3.8308\right.$, $p=0.147)$ and when Carcinus maenas was treated separately $\left(\mathrm{LRT}_{\text {Month }}: d f=2, \chi^{2}=1.9637, p=0.375\right)$. For Hemigrapsus sanguineus, however, the result revealed a seasonality effect, yet on the verge of the significance level $\left(\mathrm{LRT}_{\text {Month }}: d f=2, \chi^{2}=6.2533, p=0.044\right)$. Differences between sexes and interactions between sexes and species were not significant $\left(\mathrm{LRT}_{\mathrm{Sex}}: d f=1, \chi^{2}=2.4089, p=0.121\right.$ and $\mathrm{LRT}_{\text {Sex } \times \text { Species }}: d f=1, \chi^{2}=1.0362, p=0.3087$ ).

Overall, the native $C$. maenas specimens showed higher respiration rates than the non-native $H$. sanguineus $\left(\mathrm{LRT}_{\text {Species }}: d f=1, \chi^{2}=22.056, p<0.0001\right)$, and both species showed an increase in respiration with increasing temperatures $\left(\mathrm{LRT}_{\text {Temperature }}: d f=1, \chi^{2}=89.724\right.$, $p<0.0001$ ) (Fig. 2). The interaction between species and temperature was determined as the only relevant interaction, revealing that respiration rates increased with temperature at a higher rate in $H$. sanguineus than in $C$. maenas (LRT $_{\text {Species*Temperature }}: d f=1, \chi^{2}=13.965, p=0.0002$ ). Furthermore, respiration rates were negatively related with body mass $\left(\mathrm{LRT}_{\text {Mass }}: d f=1, \chi^{2}=57.493, p<0.0001\right)$. Respiration rates were mostly dependent on temperature and mass and less on species or the interaction between species and temperature. 

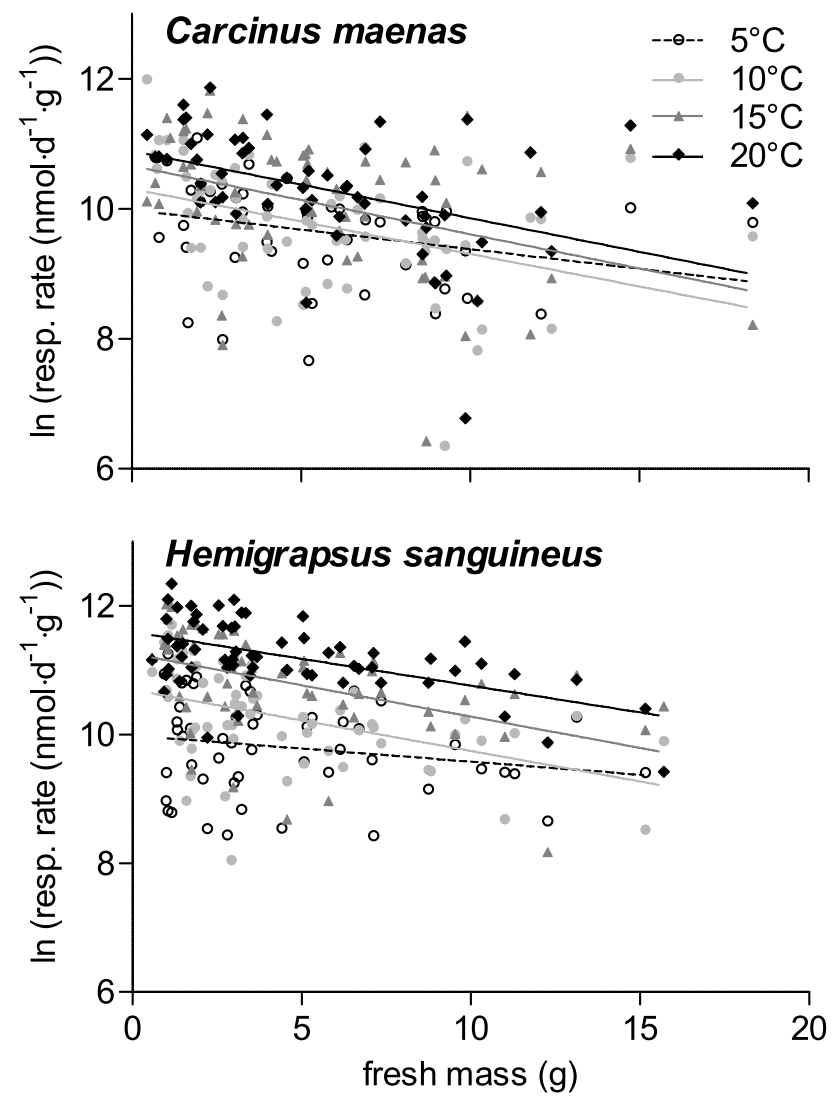

Fig. 2 Standard respiration rates for Carcinus maenas $(n=63$ ind.) and Hemigrapsus sanguineus ( $n=64$ ind.) at $5,10,15$, and $20{ }^{\circ} \mathrm{C}$. The equations of the linear regressions for standard, median, and maximum values of the frequency distributions are presented in Table 2. Original oxygen consumption data and the minimum (= standard), median, and maximum values for the frequency distributions of the original data are presented in the Supplementary Material
Linear regression lines between the crab's fresh mass and the natural logarithm of the corresponding respiration rates were parallel for measurements at 10,15 , and $20^{\circ} \mathrm{C}$ and increased with increasing temperatures. Only the regression slope of measurements at $5{ }^{\circ} \mathrm{C}$ were less steep in both species (Table 2, Fig. 2).

The specific standard respiration rates of the mass-standardized crabs increased with temperature and decreased with body mass (Fig. 3, Table 3). At 5 and $10{ }^{\circ} \mathrm{C}$, rates were similar in both species at all sizes, whereas at 15 and $20^{\circ} \mathrm{C}$ rates of $H$. sanguineus were higher than those of $C$. maenas. Overall, the $Q_{10}$ values for the standard respiration of $H$. sanguineus were higher than those of $C$. maenas (Table 4 ). Maximal respiration of both species was similar and thus the range between standard and maximal respiration higher for $C$. maenas than for $H$. sanguineus (Fig. 3). In C. maenas, the median respiration level was closer to the standard respiration, whereas in $H$. sanguineus it was closer to the maximal respiration.

\section{Respiration models}

In the two species-specific respiration models, $R$ represents the individual respiration rate $\left(\mathrm{nmol} \mathrm{g} \mathrm{g}^{-1} \mathrm{~d}^{-1}\right), m$ the crab's body mass (fresh mass, $\mathrm{g}$ ) and $T$ the environmental temperature $\left({ }^{\circ} \mathrm{C}\right)$ :

(a) $\ln R=10.05+(-0.50 \times \ln m)+(0.05 \times T)$ for $C$. maenas

(b) $\ln R=9.76+(-0.38 \times \ln m)+(0.10 \times T)$ for $H$. sanguineus.

The resulting $Q_{10}$ values of the models were independent of mass and temperature and were 1.65 for $C$. maenas and 2.72 for $H$. sanguineus.
Table 2 Regression parameters of standard, median, and maximum mass-dependent respiration measurements of Carcinus maenas and Hemigrapsus sanguineus at different seawater temperatures: $m$ represents the crab's fresh mass ( $\mathrm{g}$ ) and $R$ the corresponding respiration rate (nmol d ${ }^{-1} \mathrm{~g}^{-1}$ )

\begin{tabular}{llll}
\hline $\begin{array}{l}\text { Temperature } \\
\left({ }^{\circ} \mathrm{C}\right)\end{array}$ & Respiration & C. maenas & H. sanguineus \\
\hline 5 & Standard & $\ln R=-0.060 \times m+9.98$ & $\ln R=-0.041 \times m+9.99$ \\
& Median & $\ln R=-0.095 \times m+10.71$ & $\ln R=-0.044 \times m+10.59$ \\
& Maximum & $\ln R=-0.076 \times m+11.27$ & $\ln R=-0.049 \times m+11.06$ \\
10 & Standard & $\ln R=-0.100 \times m+10.31$ & $\ln R=-0.095 \times m+10.70$ \\
& Median & $\ln R=-0.084 \times m+10.98$ & $\ln R=-0.097 \times m+11.15$ \\
& Maximum & $\ln R=-0.068 \times m+11.40$ & $\ln R=-0.094 \times m+11.42$ \\
15 & Standard & $\ln R=-0.105 \times m+10.66$ & $\ln R=-0.097 \times m+11.25$ \\
& Median & $\ln R=-0.065 \times m+11.21$ & $\ln R=-0.092 \times m+11.72$ \\
& Maximum & $\ln R=-0.066 \times m+11.90$ & $\ln R=-0.097 \times m+11.94$ \\
& Standard & $\ln R=-0.103 \times m+10.89$ & $\ln R=-0.083 \times m+11.59$ \\
& Median & $\ln R=-0.039 \times m+11.44$ & $\ln R=-0.079 \times m+11.94$ \\
& Maximum & $\ln R=-0.062 \times m+12.20$ & $\ln R=-0.090 \times m+12.17$ \\
\hline
\end{tabular}


Fig. 3 Specific standard, median, and maximum respiration rates of mass-standardized Carcinus maenas and Hemigrapsus sanguineus of 0.5, 5.0, and $10.0 \mathrm{~g}$ fresh mass. The rates were calculated from the regressions of respiration measurements at $5,10,15$, and $20^{\circ} \mathrm{C}$ (Table 2). Error bars represent $95 \%$ confidence intervals. The equations of the third order polynomial functions (dashed lines) are presented in Table 3
Carcinus maenas
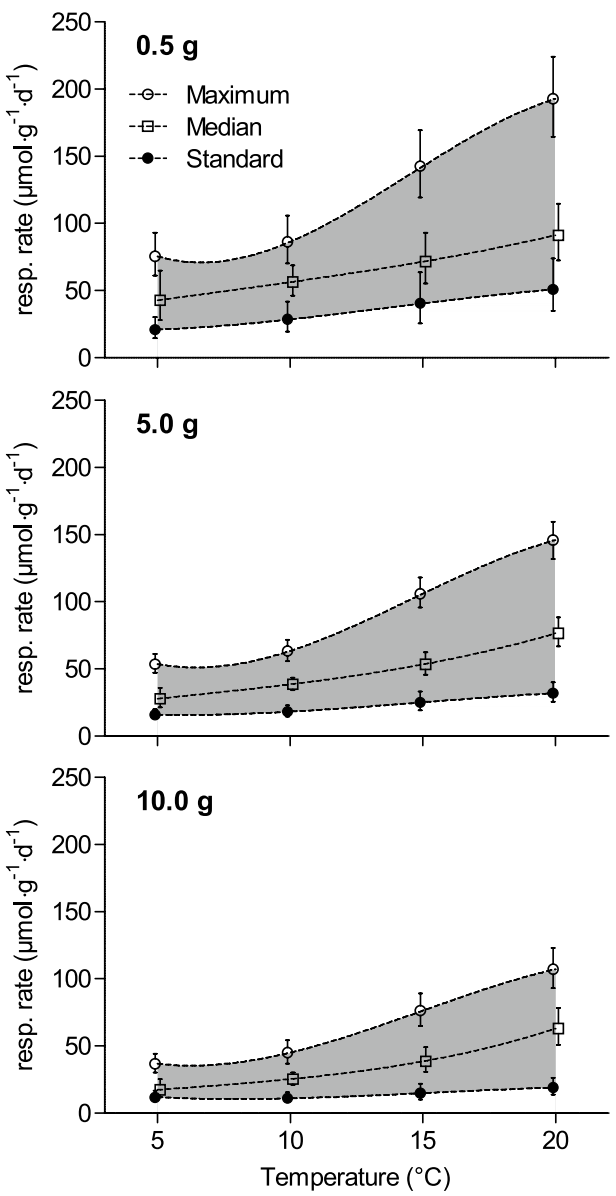

Hemigrapsus sanguineus
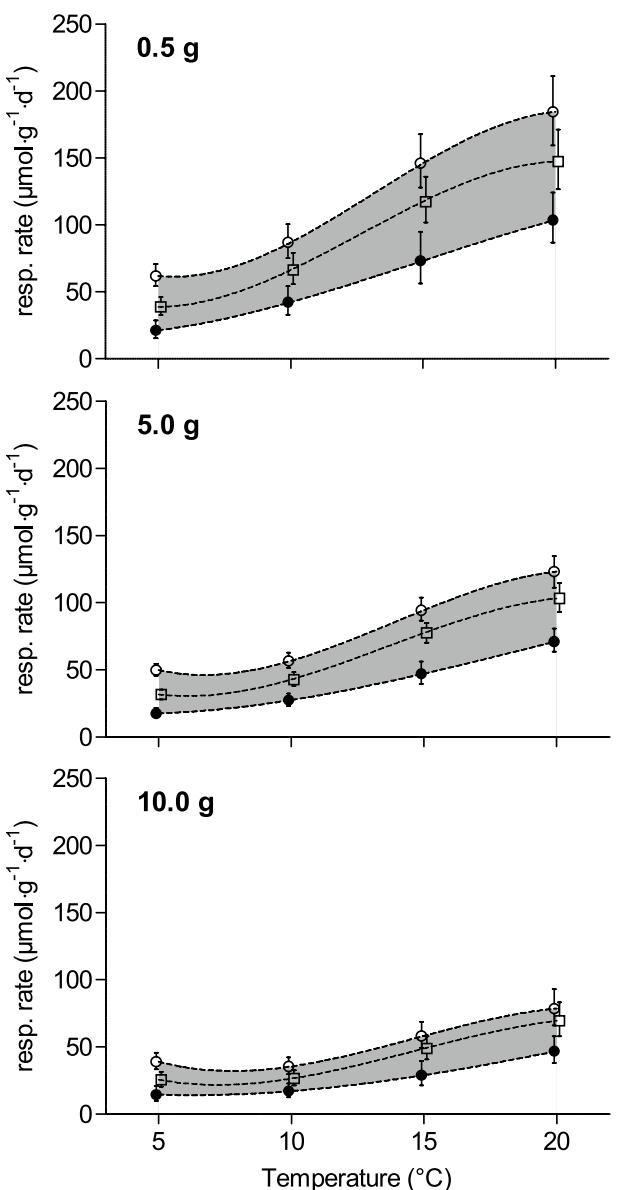

Table 3 Parameters of the fitted mass-dependent third order polynomial models for standard, median, and maximum respiration rates $R$ $\left(\mu \mathrm{mol} \mathrm{d} \mathrm{d}^{-1} \mathrm{~g}^{-1}\right)$ of Carcinus maenas and Hemigrapsus sanguineus depending on temperature $T\left({ }^{\circ} \mathrm{C}\right)$

\begin{tabular}{llll}
\hline Mass $(\mathrm{g})$ & Respiration & C. maenas & H. sanguineus \\
\hline 0.5 & Standard & $R=23.36+(-1.84) \times T+0.31 \times T^{2}+(-0.01) \times T^{3}$ & $R=20.55+(-2.59) \times T+0.62 \times T^{2}+(-0.01) \times T^{3}$ \\
& Median & $R=28.09+3.22 \times T+(-0.08) \times T^{2}+0.003 \times T^{3}$ & $R=80.26+(-18.16) \times T+2.28 \times T^{2}+(-0.06) \times T^{3}$ \\
& Maximum & $R=161.50+(-30.28) \times T+2.96 \times T^{2}+(-0.07) \times T^{3}$ & $R=126.40+(-25.44) \times T+2.88 \times T^{2}+(-0.07) \times T^{3}$ \\
5.0 & Standard & $R=23.45+(-2.78) \times T+0.29 \times T^{2}+(-0.01) \times T^{3}$ & $R=23.04+(-2.95) \times T+0.41 \times T^{2}+(-0.01) \times T^{3}$ \\
& Median & $R=17.06+2.45 \times T+(-0.09) \times T^{2}+0.01 \times T^{3}$ & $R=76.82+(-16.75) \times T+1.77 \times T^{2}+(-0.04) \times T^{3}$ \\
& Maximum & $R=112.30+(-20.92) \times T+2.08 \times T^{2}+(-0.05) \times T^{3}$ & $R=113.20+(-22.35) \times T+2.20 \times T^{2}+(-0.05) \times T^{3}$ \\
10.0 & Standard & $R=21.48+(-3.10) \times T+0.26 \times T^{2}+(-0.01) \times T^{3}$ & $R=23.99+(-3.34) \times T+0.31 \times T^{2}+(-0.004) \times T^{3}$ \\
& Median & $R=8.59+2.22 \times T+(-0.13) \times T^{2}+0.01 \times T^{3}$ & $R=69.27+(-14.74) \times T+1.36 \times T^{2}+(-0.03) \times T^{3}$ \\
& Maximum & $R=74.93+(-13.83) \times T+1.40 \times T^{2}+(-0.03) \times T^{3}$ & $R=98.06+(-19.25) \times T+1.69 \times T^{2}+(-0.04) \times T^{3}$ \\
\hline
\end{tabular}

\section{Energy expenditures of the Helgoland crab populations}

The respiration models were used to calculate standard respiration and energy expenditures of the intertidal populations of $C$. maenas and $H$. sanguineus around the island of Helgoland, Germany, in August 2014. Total abundance and biomass of $H$. sanguineus around Helgoland comprised about 21 and $59 \%$ of the values for C. maenas, respectively (Table 1).

Depending on the animal density, respiration rates of the $C$. maenas population varied from 0.5 to $1.8 \mathrm{mmol} \mathrm{O}_{2} \mathrm{~m}^{-2} \mathrm{~d}^{-1}$ and those of the $H$. sanguineus population ranged from 0.6 to $6.3 \mathrm{mmol} \mathrm{O}_{2} \mathrm{~m}^{-2} \mathrm{~d}^{-1}$ (Table 5). 
Table $4 Q_{10}$ values for standardized Carcinus maenas and Hemigrapsus sanguineus specimens of $0.5,5.0$, and $10.0 \mathrm{~g}$ fresh mass, calculated from respiration measurements at $5,10,15$, and $20^{\circ} \mathrm{C}$

\begin{tabular}{llll}
\hline Mass (g) & Temperature $\left({ }^{\circ} \mathrm{C}\right)$ & $Q_{10}$ C. maenas & $\begin{array}{l}Q_{10} H . \\
\text { san- } \\
\text { guineus }\end{array}$ \\
\hline 0.5 & $5-10$ & 1.86 & 3.92 \\
& $10-15$ & 2.00 & 3.00 \\
& $15-20$ & 1.59 & 2.00 \\
5.0 & $5-10$ & 1.30 & 2.41 \\
& $10-15$ & 1.92 & 2.94 \\
& $15-20$ & 1.62 & 2.27 \\
10.0 & $5-10$ & 0.87 & 1.40 \\
& $10-15$ & 1.82 & 2.89 \\
& $15-20$ & 1.65 & 2.61 \\
\hline
\end{tabular}

Total respiration of the entire intertidal crab populations around Helgoland was similar for both species, each accounting for about $201 \mathrm{~mol} \mathrm{O}_{2} \mathrm{~d}^{-1}$. Assuming a carnivorous diet $(\mathrm{RQ}=0.8)$, the carbon uptake rates of $C$. maenas population varied from 4.9 to $17.0 \mathrm{mg} \mathrm{C} \mathrm{m}^{-2} \mathrm{~d}^{-1}$. For the $H$. sanguineus population the values ranged between 5.8 and $60.4 \mathrm{mg} \mathrm{C} \mathrm{m}^{-2} \mathrm{~d}^{-1}$. On the basis of a herbivorous diet $(\mathrm{RQ}=1.0)$, the carbon uptake rates varied from 6.1 to $21.3 \mathrm{mg} \mathrm{C} \mathrm{m}^{-2} \mathrm{~d}^{-1}$ and 7.3 to $75.4 \mathrm{mg} \mathrm{C} \mathrm{m}^{-2} \mathrm{~d}^{-1}$ for the $C$. maenas and $H$. sanguineus populations, respectively. For the entire Helgoland intertidal, carnivorous C. maenas would consume about $1933 \mathrm{~g} \mathrm{C} \mathrm{d}^{-1}$, whereas herbivorous $C$. maenas would ingest about $2417 \mathrm{~g} \mathrm{C} \mathrm{d}^{-1}$. The daily carbon uptake of $H$. sanguineus would amount to about $1927 \mathrm{~g} \mathrm{C} \mathrm{d}^{-1}$ in case of a carnivorous diet and to $2409 \mathrm{~g} \mathrm{C} \mathrm{d}^{-1}$ in case of a purely herbivorous diet (Table 5). Correspondingly, the population energy expenditures varied from 0.2 to $0.7 \mathrm{~kJ} \mathrm{~m}^{-2} \mathrm{~d}^{-1}$ for carnivorous $C$. maenas and 0.3 to $0.9 \mathrm{~kJ} \mathrm{~m}^{-2} \mathrm{~d}^{-1}$ for herbivorous $C$. maenas. The $H$. sanguineus population requires between 0.2 and $2.5 \mathrm{~kJ} \mathrm{~m}^{-2} \mathrm{~d}^{-1}$ and 0.3 and $3.1 \mathrm{~kJ} \mathrm{~m}^{-2} \mathrm{~d}^{-1}$, being either carnivorous or herbivorous (Table 5). For the whole intertidal area of Helgoland, the total energy expenditures amounted to 80,038 and $79,790 \mathrm{~kJ} \mathrm{~d}^{-1}$ for carnivorous C. maenas and H. sanguineus, respectively. In the case of herbivorous crabs, the corresponding values are higher: 100,047 and $99,738 \mathrm{~kJ} \mathrm{~d}^{-1}$ for $C$. maenas and $H$. sanguineus, respectively (Table 5). The total energy expenditure of the $H$. sanguineus population in August 2014 was thus between 80 and $125 \%$ of the value for the $C$. maenas population.

The trends of the energy expenditures of both crab populations resemble the temperature trend during the course of the year (Fig. 4). While in spring the energy expenditure of the $H$. sanguineus population is lower than that of the $C$. maenas population, values are similarly high in summer and autumn. Calculated cumulatively, the energy expenditure of the $C$. maenas population started after winter, but increased as fast as that of $H$. sanguineus over the year and both were similar at the end of the year (Fig. 4). Depending on the feeding mode, the $C$. maenas population required between 16,040 and 20,050 MJ per year, whereas the H. sanguineus population consumed between 17,314 and 21,643 MJ per year. Thus, the cumulative energy expenditure of the $H$. sanguineus population reached $86-135 \%$ of the value for the whole C. maenas population for the whole year 2014, depending on the preferred diet of either species.

\section{Discussion}

\section{Respiration-temperature dependence}

Both species, Carcinus maenas and Hemigrapsus sanguineus, showed no significant difference in respiration between sexes. Similarly, no pronounced respiratory differences were observed between seasons, as for example noted for Northern krill Meganyctiphanes norvegica from the Ligurian Sea, Mediterranean (Saborowski et al. 2002). The significance level that $H$. sanguineus showed with regard to seasonality is, compared to other statistical results, rather vague. Overall, respiration rates resembled those of other brachyuran crabs, e.g., Ovalipes punctatus, Callinectes sapidus, C. maenas, Hemigrapsus takanoi (Du Preez 1983; Houlihan et al. 1990; Booth and McMahon 1992; Robertson et al. 2002; Shinji et al. 2009).

Respiration rates of $C$. maenas and $H$. sanguineus differed significantly in their relations between animal size and temperature. Both species showed the classical inverse exponential correlation between mass-specific respiration and body mass known as 'allometric scaling' (e.g., Du Preez 1983; Cockcroft and Wooldridge 1985; Booth and McMahon 1992; Robertson et al. 2002; Brey 2010). They also followed the classical thermodynamic relationship between standard respiration and temperature that describes an exponential increase of oxygen consumption (e.g., Frederich and Pörtner 2000; Saborowski et al. 2000; Pörtner 2002; Verberk et al. 2016). The maximum of this relationship and the subsequent drop of respiration rates beyond the critical temperature due to biochemical and biophysical limitations was not reached in either species. However, the temperature correlation was steeper in $H$. sanguineus, which was also reflected in generally higher $Q_{10}$ values. This may indicate an adaptation to warmer temperatures. For instance, higher oxygen consumption and $Q_{10}$ values were found in warm-acclimated specimens of North Sea isopods (Salomon and Buchholz 2000). In contrast, lower $Q_{10}$ values, as found for $C$. maenas, may be an adaptation to stabilize metabolic rates (Clarke 


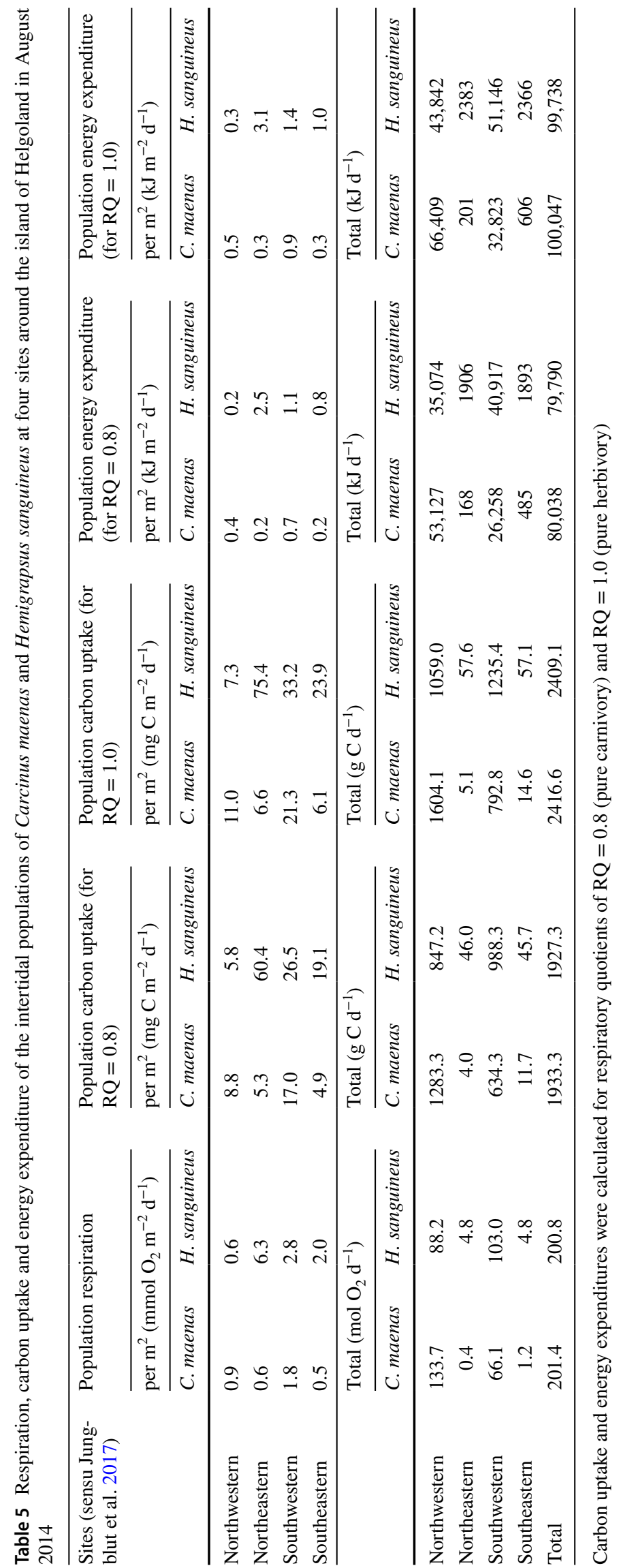



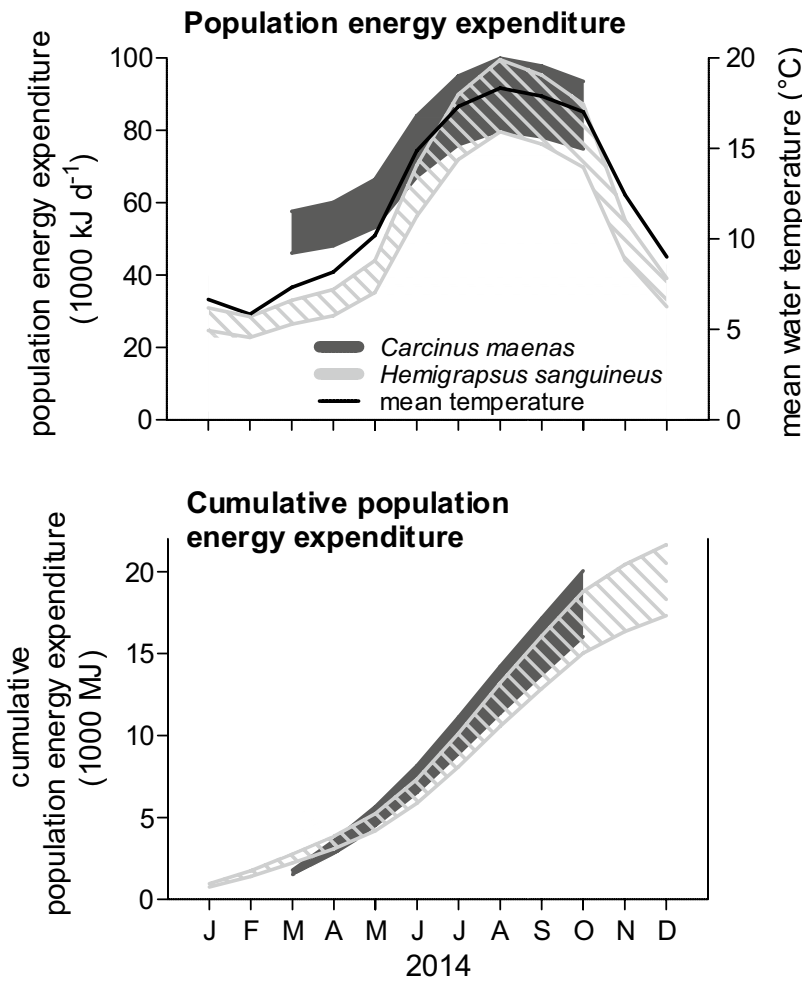

Fig. 4 Population energy expenditure of Carcinus maenas and Hemigrapsus sanguineus and mean seawater temperatures around Helgoland in 2014, per month and cumulatively. Energy expenditures were calculated for respiratory quotients of 0.8 and 1.0 (pure carnivory and herbivory, i.e., lower and upper margin of each band, resp.)

1983) and may partially explain the worldwide success of $C$. maenas as an invasive species in physically diverse habitats.

Behavior and movements of the crabs were not controlled during the measurements. Therefore, respiration rates above the minimal respiration reflect a combination of standard and routine metabolism, most likely due to enhanced physical activity (e.g., Du Preez 1983). The range between standard and maximum respiration at higher temperatures is wider in C. maenas than in H. sanguineus, indicating an enhanced potential for occasional bursts of activity in this species. Such activity bursts might be more balanced and probably more frequent in $H$. sanguineus, as its median rates are closer to its maximal respiration rates. Several studies provide evidence of a generally higher agility and activity of $H$. sanguineus compared to $C$. maenas. The invasion of $H$. sanguineus along the US east coast was generally accompanied by a massive decrease of $C$. maenas (Lohrer and Whitlatch 2002; Kraemer et al. 2007; O'Connor 2014). Likewise, $H$. sanguineus was found to be highly mobile (Brousseau et al. 2002) and it dominated C. maenas in competition for food and shelter (Jensen et al. 2002).

\section{Metabolic energy expenditure}

The total energy expenditure per site and species is obviously dependent on the density and biomass of the crabs. Considering the biomass values of August 2014, the energy expenditures for $C$. maenas and H. sanguineus are in the same order of magnitude for each site. Consequently, the August values for the entire Helgoland intertidal zone are similar, even if the biomass of $H$. sanguineus is generally lower than that of $C$. maenas (Table 1). The energy expenditure of $C$. maenas exceeds that of $H$. sanguineus during most of the year, but it is similar during summer. Due to the absence of $C$. maenas from the intertidal area in winter (see "Materials and methods"), the cumulative energy expenditure of the two species for the whole year 2014 was very similar. Generally, the energy expenditures calculated for both species are first assessments, as these laboratory measurements could not consider field conditions such as locomotory activity, photoperiod or exposure to air during low tide that might have an influence on metabolic rates (e.g., Dehnel 1958; Taylor et al. 1977).

The energetic expenditure of the crabs is relatively small compared to the total primary production in rocky intertidal areas. The annual carbon uptake of $C$. maenas and $H$. sanguineus in the Helgoland intertidal ranges between 2.1 and $2.6 \mathrm{~g} \mathrm{C} \mathrm{m}^{-2}$, and between 2.2 and $2.8 \mathrm{~g} \mathrm{C} \mathrm{m}^{-2}$, respectively (derived from the cumulative energy expenditure for 2014). Unfortunately, no primary production data are available for the Helgoland intertidal area. For kelp forests, as for example present in the subtidal area around Helgoland, a value of about $2 \mathrm{~kg} \mathrm{C} \mathrm{m}^{-2}$ year $^{-1}$ is established (Thomas 2002). For a similar rocky intertidal region, the Ria of Vigo (northwestern Spain), a value of $416 \mathrm{~g} \mathrm{C} \mathrm{m}^{-2}$ year $^{-1}$ was reported (Niell 1977). A Wadden Sea intertidal sand flat had a primary production of $81.2 \mathrm{mg} \mathrm{C} \mathrm{m}^{-2} \mathrm{~d}^{-1}$ and a consumption of $0.84 \mathrm{mg} \mathrm{C} \mathrm{m}^{-2} \mathrm{~d}^{-1}$ for C. maenas (Baird et al. 2004). Both examples indicate that primary production is not a limiting resource in intertidal areas.

The Helgoland population of $C$. maenas is not or not yet suffering from the invasion of $H$. sanguineus, since the abundance of both crab species together in the Helgoland intertidal roughly doubled from 2009 to 2014 . However, abundances of $H$. sanguineus around Helgoland may continue to increase (Jungblut et al. 2017). A considerably higher density of $H$. sanguineus may then have stronger effects on the community patterns in the rocky intertidal. The ecological impact of $C$. maenas on this area was previously described as rather limited (Janke 1990). The feeding ecology of $H$. sanguineus around Helgoland is not yet fully understood. If both species are opportunistic omnivores, competition for food can be expected (e.g., Ropes 1968; Tyrell and Harris 1999; Lohrer et al. 2000b; Griffen et al. 2012). If $H$. sanguineus prefers an herbivorous diet, competition would 
be less pronounced, but $H$. sanguineus' energy expenditure would exceed that of $C$. maenas. However, macroalgae are not a limiting resource in the Helgoland intertidal.

In the nearby Wadden Sea, another invader, the Asian brush-clawed shore crab, Hemigrapsus takanoi, is also present in high abundances in addition to $H$. sanguineus and $C$. maenas (Landschoff et al. 2013). Here, competition for food could be stronger and more complex, as macroalgae are not very abundant in the Wadden Sea intertidal zone. Energy flow models of this region should be updated to account for the impact of those successful invasive crab species (Baird et al. 2004, 2007, 2012).

\section{Conclusions}

Since 2007, Hemigrapsus sanguineus has successfully invaded the rocky intertidal around Helgoland and established a prospering population. Abundance and biomass of the invader have reached values as high as 21 and 59\%, respectively, of those recorded for the native Carcinus maenas. However, depending on the diet, the energy expenditures of the invader reached $80-125 \%$ (for August 2014) and 86-135\% (for the whole year 2014) of the values calculated for the native crab. Energetic requirements of $H$. sanguineus in their new habitat are thus in the same range as those of C. maenas.

Present warming trends in Helgoland waters attributed to climate change (Wiltshire and Manly 2004) and the fourfold higher warming projection for the North Sea, compared to the global average (Belkin 2009), will most likely be favorable for $H$. sanguineus. Increasing ambient temperatures may accelerate its growth and facilitate reproduction. Furthermore, increasing human influence and subsequent alterations in coastal habitats such as the creation of artificial hard substrate are also known to promote non-indigenous species in competitive situations (Byers 2002; Bulleri and Chapman 2010). Consequently, we predict that the overall energetic impact of $H$. sanguineus will increase, while asserting competitive dominance over its native ecological equivalent $C$. maenas. To assess the ecological influence of the invader more comprehensively, subsequent studies on, e.g., dietary preferences and competitive interactions are needed. Prevalence of the invader will eventually have implications for the original community patterns in rocky intertidal areas. Studies of the community impact of $H$. sanguineus in invaded habitats are, however, still pending.

Acknowledgements We thank the staff of the Biologische Anstalt Helgoland and especially Dr. Jan Beermann for laboratory and temperature-controlled room space and for support, whenever needed. Hendrik Pehlke calculated the areas of the intertidal sites around Helgoland. Seawater temperature data were provided by the COSYNA system operated by Helmholtz-Zentrum Geesthacht, Zentrum für
Material- und Küstenforschung GmbH. We are grateful to three reviewers, whose constructive comments and suggestions greatly improved the manuscript. This study was partly supported by a RISE Internship Grant from the German Academic Exchange Service (DAAD) to Morgan L. McCarthy.

\section{Compliance with ethical standards}

Conflict of interest The authors declare that they have no conflicts of interest.

Ethical approval All applicable international, national, and institutional guidelines for the care and use of the marine invertebrate animals were followed in this study.

\section{References}

Aagaard A, Warman CG, Depledge MH (1995) Tidal and seasonal changes in the temporal and spatial distribution of foraging Carcinus maenas in the weakly tidal littoral zone of Kerteminde Fjord, Denmark. Mar Ecol Prog Ser 122:165-172

Baird D, Asmus H, Asmus R (2004) Energy flow of a boreal intertidal ecosystem, the Sylt-Rømø Bight. Mar Ecol Prog Ser 279:45-61

Baird D, Asmus H, Asmus R (2007) Trophic dynamics of eight intertidal communities of the Sylt-Røm $\varnothing$ Bight ecosystem, northern Wadden Sea. Mar Ecol Prog Ser 351:25-41

Baird D, Asmus H, Asmus R (2012) Effect of invasive species on the structure and function of the Sylt-Røm $\varnothing$ Bight ecosystem, northern Wadden Sea, over three time periods. Mar Ecol Prog Ser 462:143-162

Bartsch I, Tittley I (2004) The rocky intertidal biotopes of Helgoland: present and past. Helgol Mar Res 58:289-302

Bates D, Maechler M, Bolker B, Walker S (2015) Fitting linear mixedeffects models using lme4. J Stat Softw 67:1-48

Belkin IM (2009) Rapid warming of Large Marine Ecosystems. Prog Oceanogr 81:207-213

Bode M, Schukat A, Hagen W, Auel H (2013) Predicting metabolic rates of calanoid copepods. J Exp Mar Biol Ecol 444:1-7

Booth CE, McMahon BR (1992) Aerobic capacity of the blue crab, Callinectes sapidus. Physiol Zool 65:1074-1091

Breen E, Metaxas A (2012) Predicting the interactions between "ecologically equivalent" indigenous and nonindigenous brachyurans. Can J Fish Aquat Sci 69:983-995

Brey T (2010) An empirical model for estimating aquatic invertebrate respiration. Methods Ecol Evol 1:92-101

Brockerhoff A, McLay C (2011) Human mediated spread of alien crabs. In: Galil BS, Clark PF, Carlton JT (eds) In the wrong place-alien marine crustaceans: distribution, biology and impacts. Springer Science + Business Media, Dordrecht, pp 27-106

Brousseau DJ, Baglivo JA, Filipowicz A, Sego L, Alt C (2002) An experimental field study of site fidelity and mobility in the Asian shore crab, Hemigrapsus sanguineus. Northeast Nat 9:381-390

Bulleri F, Chapman MG (2010) The introduction of coastal infrastructure as a driver of change in marine environments. J Appl Ecol 47:26-35

Byers JE (2002) Impact of non-indigenous species on natives enhanced by anthropogenic alteration of selection regimes. Oikos 97:449-458

Carlton JT, Cohen AN (2003) Episodic global dispersal in shallow water marine organisms: the case history of the European shore crabs Carcinus maenas and C. aestuarii. J Biogeogr 20:1809-1820 
Clarke A (1983) Life in cold water: the physiological ecology of polar marine ectotherms. Oceanogr Mar Biol Annu Rev 21:341-453

Cockcroft AC, Wooldridge T (1985) The effects of mass, temperature and molting on the respiration of Macropetasma africanus Balss (Decapoda: Penaeoidea). Comp Biochem Physiol A 81:143-148

Crear BJ, Forteath GNR (2001) Flow-rate requirements for captive western rock lobsters (Panulirus cygnus): effects of body weight, temperature, activity, emersion, daily rhythm, feeding and oxygen tension on oxygen consumption. Mar Freshwater Res 52:763-771

Crothers JH (1967) The biology of the shore crab Carcinus maenas (L.). 1. The background—anatomy, growth and life history. Field Stud 2:407-434

Dauvin J-C, Rius AT, Ruellet T (2009) Recent expansion of two invasive crabs species Hemigrapsus sanguineus (de Haan, 1835) and H. takanoi Asakura and Watanabe 2005 along the Opal Coast, France. Aquat Invasions 4:451-465

Dehnel PA (1958) Effect of photoperiod on the oxygen consumption of two species of intertidal crabs. Nature 181:1415-1417

Delaney DG, Sperling CD, Adams CS, Leung B (2008) Marine invasive species: validation of citizen science and implications for natural monitoring networks. Biol Invasions 10:117-128

Du Preez HH (1983) The effects of temperature, season and activity on the respiration of the three spot swimming crab, Ovalipes punctatus. Comp Biochem Physiol A 75:353-362

Epifanio CE (2013) Invasion biology of the Asian shore crab Hemigrapsus sanguineus: a review. J Exp Mar Biol Ecol 441:33-49

Frederich M, Pörtner HO (2000) Oxygen limitation of thermal tolerance defined by cardiac and ventilatory performance in spider crab, Maja squinado. Am J Physiol Regul Integr Comp Physiol 279:R1531-R1538

Fukui Y (1988) Comparative studies on the life history of grapsid crabs (Crustacea, Brachyura) inhabiting intertidal cobble and boulder shores. Publ Seto Mar Biol Lab 33:121-162

Gnaiger E (1983) Calculation of energetic and biochemical equivalents of respiratory oxygen consumption. In: Gnaiger E, Forstner $\mathrm{H}$ (eds) Polarographic oxygen sensors. Springer, Berlin, pp 337-345

Griffen BD, Altman I, Bess BM, Hurley J, Penfield A (2012) The role of foraging in the success of invasive Asian shore crabs in New England. Biol Invasions 14:2545-2558

Griffen BD, Vogel M, Goulding L, Hartman R (2015) Energetic effects of diet choice by invasive Asian shore crabs: implications for persistence when prey is scarce. Mar Ecol Prog Ser 522:181-192

Grosholz E (2002) Ecological and evolutionary consequences of coastal invasions. Trends Ecol Evol 17:22-27

Houlihan DF, Waring CP, Mathers E, Gray C (1990) Protein synthesis and oxygen consumption of the shore crab Carcinus maenas after a meal. Physiol Zool 63:735-756

Hu M-YA, Hagen W, Jeng M-S, Saborowski R (2012) Metabolic energy demand and food utilization of the hydrothermal vent crab Xenograpsus testudinatus (Crustacea: Brachyura). Aquat Biol 15:11-25

Ikeda T (1985) Metabolic rates of epipelagic marine zooplankton as a function of body mass and temperature. Mar Biol 85:1-11

Ikeda T (2013) Respiration and ammonia excretion of euphausiid crustaceans: synthesis toward a global-bathymetric model. Mar Biol 160:251-262

Ikeda T, Torres JJ, Hernandez-Leon S, Geiger SP (2000) Metabolism. In: Harris R, Wiebe P, Lenz J, Skjøldal H, Huntley M (eds) ICES zooplankton methodology manual. Academic Press, San Diego, pp 455-532

Ikeda T, Sano F, Yamaguchi A (2007) Respiration in marine pelagic copepods: a global-bathymetric model. Mar Ecol Prog Ser 339:215-219

Janke K (1986) Die Makrofauna und ihre Verteilung im NordostFelswatt von Helgoland. Helgoländer Meeresunters 40:1-55
Janke K (1990) Biological interactions and their role in community structure in the rocky intertidal of Helgoland (German Bight, North Sea). Helgoländer Meeresunters 44:219-263

Jensen GC, McDonald PS, Armstrong DA (2002) East meets west: competitive interactions between green crab Carcinus maenas, and native and introduced shore crab Hemigrapsus spp. Mar Ecol Prog Ser 225:251-262

Jungblut S, Beermann J, Boos K, Saborowski R, Hagen W (2017) Population development of the invasive crab Hemigrapsus sanguineus (De Haan, 1853) and its potential native competitor Carcinus maenas (Linnaeus, 1758) at Helgoland (North Sea) between 2009 and 2014. Aquat Invasions 12:85-96

Kraemer GP, Sellberg M, Gordon A, Main J (2007) Eight-year record of Hemigrapsus sanguineus (Asian shore crab) invasion in western Long Island Sound estuary. Northeast Nat 14:207-224

Landschoff J, Lackschewitz D, Kesy K, Reise K (2013) Globalization pressure and habitat change: Pacific rocky shore crabs invade armored shorelines in the Atlantic Wadden Sea. Aquat Invasions 8:77-87

Lewis EG, Haefner PA (1976) Oxygen consumption of the blue crab, Callinectes sapidus Rathbun, from proecdysis to postecdysis. Comp Biochem Physiol A 54:55-60

Lohrer AM, Whitlatch RB (2002) Interactions among aliens: apparent replacement of one exotic species by another. Ecology 83:719-732

Lohrer AM, Fukui Y, Wada K, Whitlatch RB (2000a) Structural complexity and vertical zonation of intertidal crabs, with focus on habitat requirements of the invasive Asian shore crab, Hemigrapsus sanguineus (de Haan). J Exp Mar Biol Ecol 244:203-217

Lohrer AM, Whitlatch RB, Wada K, Fukui Y (2000b) Home and away: comparisons of resource utilization by a marine species in native and invaded habitats. Biol Invasions 2:41-57

Loy A, Hofman H (2014) HLMdiag: A suite of diagnostics for hierarchical linear models in R. J Stat Softw 56:1-28

McDermott JJ (1998) The western Pacific brachyuran Hemigrapsus sanguineus (Grapsidae), in its new habitat along the Atlantic coast of the United States: reproduction. J Crustacean Biol 18:308-316

Micu D, Niţă V, Todorova V (2010) First record of the Japanese shore crab Hemigrapsus sanguineus (de Haan, 1835) (Brachyura: Grapsoidea: Varunidae) from the Black Sea. Aquat Invasions 5:S1-S4

Naylor JK, Taylor EW, Bennett DB (1997) The oxygen uptake of ovigerous edible crabs (Cancer pagurus) (L.) and their eggs. Mar Fresh Behav Physiol 30:29-44

Niell FX (1977) Rocky intertidal benthic systems in temperate seas: a synthesis of their functional performances. Helgoland Wiss Meer 30:315-333

O'Connor NJ (2014) Invasion dynamics on a temperate rocky shore: from early invasion to establishment of a marine invader. Biol Invasions 16:73-87

Pörtner HO (2002) Climate variation and the physiological basis of temperature dependent biogeography: systemic to molecular hierarchy of thermal tolerance in animals. Comp Biochem Physiol A 132:739-761

R Development Core Team (2015) R: a language and environment for statistical computing. R Foundation for Statistical Computing, Vienna, Austria (URL:http://www.R-project.org)

Reid DG, Aldrich JC (1989) Variations in response to environmental hypoxia of different colour forms of the shore crab, Carcinus maenas. Comp Biochem Physiol A 92:535-539

Robertson RF, Meagor J, Taylor EW (2002) Specific dynamic action in the shore crab, Carcinus maenas (L.), in relation to acclimation temperature and to the onset of the emersion response. Physiol Biochem Zool 75:350-359

Roman J, Palumbi SR (2004) A global invader at home: population structure of the green crab, Carcinus maenas, in Europe. Mol Ecol 13:2891-2898 
Ropes JW (1968) The feeding habits of the green crab, Carcinus maenas (L.). Fish Bull 67:183-203

Ruiz GM, Fofonoff PW, Carlton JT, Wonham MJ, Hines AH (2000) Invasion of coastal marine communities in North America: apparent patterns, processes, and biases. Annu Rev Ecol Evol Syst 31:481-531

Saborowski R, Salomon M, Buchholz F (2000) The physiological response of Northern krill (Meganyctiphanes norvegica) to temperature gradients in the Kattegat. Hydrobiologia 426:156-160

Saborowski R, Bröhl S, Tarling GA, Buchholz F (2002) Metabolic properties of Northern krill, Meganyctiphanes norvegica, from different climatic zones. I. Respiration and excretion. Mar Biol 140:547-556

Salomon M, Buchholz F (2000) Effects of temperature on the respiration rates and the kinetics of citrate synthase in two species of Idotea (Isopoda, Crustacea). Comp Biochem Physiol B 125:71-81

Salonen K, Sarvala J, Hakala I, Viljanen M-L (1976) The relation of energy and organic carbon in aquatic invertebrates. Limnol Oceanogr 21:724-730

Schubart CD (2003) The East Asian shore crab Hemigrapsus sanguineus (Brachyura: Varunidae) in the Mediterranean Sea: an independent human-mediated introduction. Sci Mar 67:195-200

Shinji J, Strüssmann CA, Wilder MN, Watanabe S (2009) Short-term responses of the adults of the common Japanese intertidal crab, Hemigrapsus takanoi (Decapoda: Brachyura: Grapsoidea) at different salinities: osmoregulation, oxygen consumption, and ammonia excretion. J Crustacean Biol 29:269-272

Simberloff D, Martin J-L, Genovesi P, Maris V, Wardle DA, Aronson J, Courchamp F, Galil B, Garcia-Berthou E, Pascal M, Pyšek P, Sousa R, Tabacchi E, Vila M (2013) Impacts of biological invasions: what's what and the way forward. Trends Ecol Evol 28:58-66
Stephenson EH, Steneck RS, Seeley RH (2009) Possible temperature limits to range expansion of non-native Asian shore crabs in Maine. J Exp Mar Biol Ecol 375:21-31

Styrishave B, Rewitz K, Andersen O (2004) Frequency of moulting by shore crabs Carcinus maenas (L.) changes their colour and their success in mating and physiological performance. J Exp Mar Biol Ecol 313:317-336

Taylor EW, Butler PJ, Al-Wassia A (1977) The effect of a decrease in salinity on respiration, osmoregulation and activity in the shore crab, Carcinus maenas (L.) at different acclimation temperatures. J Comp Physiol 119:155-170

Thomas D (2002) Seaweeds. Smithsonian Institution Press, Washington DC in association with The Natural History Museum London

Tyrell MC, Harris LG (1999) Potential impact of the introduced Asian shore crab, Hemigrapsus sanguineus, in northern New England: Diet, feeding preferences, and overlap with the green crab, Carcinus maenas. Marine Bioinvasions: Proc First Nat Conf, Cambridge, MA, 24-27 January 1999:208-220

Verberk WCEP, Bartolini F, Marshall DJ, Pörtner HO, Terblanche JS, White CR, Giomi F (2016) Can respiratory physiology predict thermal niches? Ann NY Acad Sci 1365:73-88

Williams AB, McDermott JJ (1990) An eastern United States record for the western Indo-Pacific crab, Hemigrapsus sanguineus (Crustacea: Decapoda: Grapsidae). Proc Biol Soc Wash 103:108-109

Willmer P, Stone G, Johnston I (2000) Environmental physiology of animals. Blackwell Science, Oxford

Wiltshire KH, Manly BFJ (2004) The warming trend at Helgoland Roads, North Sea: phytoplankton response. Helgol Mar Res $58: 269-273$ 